\title{
Interhousehold variability and its effects on seed circulation networks: a case study from northern Cameroon
}

\author{
Jean Wencélius $^{1,2}$, Mathieu Thomas $^{3,4,5}$, Pierre Barbillon ${ }^{6}$ and Eric Garine $^{1,2}$
}

\begin{abstract}
We present a detailed ethnographic case study of sorghum seed acquisitions in a smallholder farming society in northern Cameroon. The effects of variability in household demographics and socioeconomic status on observed patterns of seed provisioning are explored alongside other variables such as age and gender. Our data set comprised 223 seed acquisition events. Independence tests (Pearson's chi-square and Fisher's exact tests) were carried out to test for significant dependencies between individual- or householdlevel characteristics and properties of seed acquisition events (categories of seed source, social relationship of exchange, and type of landrace). Results indicate that wealth is a structuring factor of the local seed circulation network in as much as it is highly correlated with household composition and size. Members from wealthy households benefit from a more diverse set of seed sources. Their greater number of coresidents and the importance of intrahousehold dynamics of seed transactions also play a role in making wealthy farmers more seed secure than others. The methodological implications of our findings indicate that when documenting seed exchange networks, the collection of data through a single informant or the undertaking of social network analyses at the household level may induce important biases.
\end{abstract}

Key Words: crop diversity; interhousehold variability; Masa; northern Cameroon; seed exchange networks; socialnetwork analysis; sorghum

\section{INTRODUCTION}

In the agrobiodiversity literature, a growing interest has been directed toward the understanding of local seed systems (Almekinders et al. 1994, Thiele 1999), their role in the maintenance of in situ diversity (Zimmerer 1991, Bellon 2004, Hodgkin et al. 2007, Coomes 2010), and the ways through which they affect the biological and genetic dynamics of crop diversity (Louette et al. 1997, Pressoir and Berthaud 2004, Dyer et al. 2011, Thomas et al. 2012). In most farming societies across the world, farmers rely on local seed systems for seed provisioning (Seboka and Deressa 1999, Bentley et al. 2011). Local seed systems are often referred to as informal because the bulk of seeds used are neither bred by nor distributed through governmental, scientific, or commercial institutions (Sperling and McGuire 2010, Louwaars and de Boef 2012). Farmer seed transactions, however, are embedded within pre-existing networks of social relationships (Boster 1986, Badstue et al. 2006, McGuire 2008, Ellen and Platten 2011), which, quite formally, structure the patterns of seed circulation according to local norms and values (Leclerc and Coppens d'Eeckenbrugge 2012). Tools developed in the field of social network analysis (SNA) have, in the past few years, offered promising perspectives on the analysis of the social mechanisms underlying the circulation of seed in smallholder farming societies (Subedi et al. 2003, Pautasso et al. 2013, Reyes-García et al. 2013, Poudel et al. 2015). Our case study offers an anthropologically informed contribution to this line of research.

Recent studies, carried out in different cultural settings, have shown how community-level properties (i.e., ethnicity, cultural norms, and social rules) substantially structure local seed systems and the distribution of crop diversity (Longley 2000, Perales et al. 2005, Delêtre et al. 2011, Garine et al. 2014, Labeyrie et al. 2014, Wencélius and Garine 2014). At a much finer scale, household-level properties and individual characteristics have also been explored to uncover differential patterns of seed seeking and seed provisioning behaviors within communities. Studies have shown that gender (Zimmerer 2003, Ban and Coomes 2004, Chambers and Brush 2010, Ricciardi 2015), age (Alvarez et al. 2005), farmer expertise (Subedi et al. 2003, Calvet-Mir et al. 2012, Kawa et al. 2013, Reyes-García et al. 2013), richness of crop diversity (Ban and Coomes 2004, Alvarez et al. 2005, Calvet-Mir et al. 2012, Reyes-García et al. 2013), and household socioeconomic status (Louette et al. 1997, Alvarez et al. 2005, Nagarajan et al. 2007, van Etten and de Bruin 2007, McGuire 2008, Stromberg et al. 2010, Rana et al. 2011, Samberg et al. 2013, Poudel et al. 2015) are important factors in understanding the structure of seed circulation networks. Of particular interest for our case study are those dimensions related to household socioeconomic status. Whereas the abovementioned studies have taken into account such variables as size of cropped area, market integration, and overall wealth, very few have investigated the potential effects of household size and demographics, although notable exceptions are provided by Nagarajan et al. (2007), Stromberg et al. (2010), and van Etten and de Bruin (2007).

Failure to account for household demographics and intrahousehold dynamics stems from intertwined theoretical and methodological shortcomings. Most of the cited case studies have used households as the unit of analysis, and information on household composition is often scant. Such a use implies that subsistence practices and strategies are uniform across household members. The assumption is revealed by the general trend of collecting household-level data by interviewing a single household member ("household heads" are often preferred), whose answers are considered representative of the household as a whole (van Etten and de Bruin 2007, Stromberg et al. 2010, Abay et al. 2011, Kawa et al. 2013, Samberg et al. 2013, Ricciardi 2015). Research designs in which several household members are interviewed are

\footnotetext{
${ }^{1}$ Université Paris Ouest, ${ }^{2}$ Laboratoire d'Ethnologie et de Sociologie Comparative (LESC - UMR 7186), ${ }^{3}$ INRA - UMR 0320/UMR 8120 Génétique Quantitative et Évolution, ${ }^{4} \mathrm{CNRS}$, Centre d'Écologie Fonctionnelle et Évolutive (CEFE - UMR 5175), ${ }^{5} \mathrm{CESAB} / \mathrm{FRB},{ }^{6} \mathrm{UMR}$ MIA-Paris, AgroParisTech, INRA, Université Paris-Saclay
} 
rare (Alvarez et al. 2005, Chambers and Brush 2010). To our knowledge, with the exception of Violon et al. (2016), no researchers have systematically interviewed all household members.

We argue that undertaking SNA at the household level and with data gathered through a single household representative may generate important biases. Anthropologists have indicated that household, as a notion, is difficult to define cross-culturally. Indeed, it encompasses residential formations ranging from nuclear families to extended kin groups (Netting et al. 1984, Augustins 1998, Niehof 2011). Households also vary in size and composition within a community (Goody 1958). Variation in household demographics may affect individual farmers' seed seeking behaviors because those living in large households are provided with a larger set of opportunities to acquire seeds (i.e., with coresidents) than are those from smaller households. Although households are a relevant unit of analysis for many subsistence-related practices, different household members may carry out their subsistence activities independently and adopt distinct, occasionally competing, strategies (Raynaut 1977, Gastellu and Dubois 1997, Vazquez-Garcia 2003). In farming societies where the latter is true, it can be expected that household members do not engage in local seed circulation networks in an equivalent manner. Such a hypothesis is supported by the documentation of gender- and age-specific patterns of seed acquisition in the literature.

We offer a case study of sorghum seed acquisitions in a rural village of northern Cameroon for which individual farmers are the unit of analysis, and all adult members of surveyed households were interviewed. We explore the biases that would have been induced had we chosen households as the network nodes or had we interviewed household heads alone. Furthermore, we analyze the effects of farmer attributes (age, gender, and socioeconomic status of the household) on characteristics of network edges (type of recipient-provider relationship and category of acquired landrace) and argue that household socioeconomic status is a key factor in understanding the seed circulation network at hand. The structuring effects of varying household characteristics on individuals' behavior may only be revealed by taking into account intrahousehold dynamics of seed transactions and by systematically documenting acquisition events of all household members. We discuss the methodological implications of our results for future research applying SNA to seed circulation networks.

\section{METHODS}

Study site: gendered division of labor and household composition Our research was conducted in Nuldayna (1626 inhabitants in 2010), a rural village in northern Cameroon, in which in-depth ethnographic fieldwork on local knowledge and management of crop diversity had been conducted over 22 months from 2009 to 2012. The village is located in the semi-arid Logone floodplains, where the climate is markedly seasonal with a short rainy season (May to October) concentrating the bulk of agriculture-related work. The villagers of Nuldayna are Masa agro-pastoralists who mainly rely on agricultural production for subsistence. Cattle are mainly used as a source of capital and as an essential currency for esteemed social transactions, particularly as bridewealth
(Garine 1964, Dumas-Champion 1983). Cattle and polygyny are perceived as the key components of success, wealth, and prestige. While the acquisition of cattle and the ability to marry several wives is the result of the male household head's own trajectory, other household members, including women, benefit materially and gain prestige from such wealth. Members from wealthy households have greater access to cattle, land, and tools. For these reasons, wealth is considered a household characteristic rather than an individual one because its benefits (e.g., possession of an ox-plough, ability to sell a cow in case of food shortage, higher number of coresidents to rely on) are made available to all household members.

Masa social organization is patrilineal (descent is recorded through the male line along which inheritance occurs), residence is patrilocal (men take up residence in their father's village, and newlywed women move from their father's village to their husband's), and marriage is strongly exogamous (weddings between members sharing a same ancestor in the patrilineal line are not allowed). The combination of these three social rules plays an important role in the territorial inscription of social organization. Within a village, all men are kin-related through patrilineal ties, and all married women are "strangers," born in other villages and belonging to different patrilineal groups (Wencélius and Garine 2014).

Farmers mainly grow sorghum, pearl millet, cowpeas, groundnuts, and cotton. Sorghum is the staple crop with which daily meals are prepared and to which farmers dedicate most of their land and labor. It is also the crop presenting the highest infraspecific diversity. In Nuldayna, > 20 different landraces were inventoried (Garine et al. 2013). Although farmers often produce their own seeds from year to year, frequent food shortages or climatic incidents (e.g., short drought after sowing) lead to regular seed loss. Seed loss combined with farmers' curiosity for novel landraces contribute to important farmer-to-farmer seed transfers, which ensure seed availability and contribute to maintaining overall diversity both at farm and community levels. Markets also prove to be a regular seed source for farmers, and the importance of markets for agrobiodiversity conservation has been documented in other contexts (Lipper et al. 2009).

Whereas some crops are gender specific (e.g., groundnuts and Bambara nuts are grown mostly by women, and cotton is grown mostly by men), sorghum is grown in equivalent proportions by both men and women. Not only do men and women contribute equally to the different tasks concerning sorghum cultivation, but they autonomously grow their own fields and possess their own granaries. Within a household, all members carry out their production activities independently and control their harvest. However, the household head (eldest married man), in addition to his own "private" fields, manages a "common" field in which he is entitled to request labor from all household members. Intrahousehold cooperation in the other fields can vary greatly from household to household. Such a pattern of household organization is quite common in the region (Stone et al. 1995, Violon et al. 2016). In monogamous households, husband and wife tend to work together in their respective fields; in polygamous ones, women usually work alone with the aid of their unmarried children. Seed selection is carried out during harvest by the field owner, whether male or female, and eventually by those helping 
Table 1. Characteristics of the survey sample.

\begin{tabular}{lcccc}
\hline \hline Variable & Total & & Household socioeconomic status \\
\cline { 3 - 5 } & & Wealthy & Intermediate & Poor \\
\hline Number of households in village & 183 & $13(7.1 \%)$ & $55(30.1 \%)$ & $155(84.7 \%)$ \\
Number of households interviewed & 15 & 4 & 6 & 5 \\
Number of informants & 70 & 36 & 22 & 12 \\
Number of males interviewed & 24 & 11 & 9 & 4 \\
Number of females interviewed & 46 & 25 & 13 & 8 \\
\hline
\end{tabular}

out. Seeds may also be selected later on from the sorghum panicles fetched out of the granaries on a daily basis for food preparation. Each field owner is responsible for the storage and, at the onset of the rainy season, the preparation of his or her own seed lots.

The minimal household composition is that of husband and wife or wives along with their children. However, it is common for married sons to dwell with their spouse(s) in their father's household. Also, after the loss of their father, full-siblings may continue sharing the same household, sometimes indefinitely. In such cases, the Masa consider the eldest brother to be the household head. Farmers' investment in agricultural activities varies with age. The youngest farmers, whether married or not, either live in their parents' household or have just founded their own. They rely heavily on the assistance of their parents for access to means of production such as land, tools, and seeds. Mid-aged farmers are usually married, live in their own household with young children, and are fully engaged in agricultural work. They are usually eager to expand the size of their fields and to try out new species and landraces. The eldest farmers' involvement in farming tends to decline because they may benefit from the assistance of their teenage or adult children living in their household.

Despite the relevance of the household as the unit of investigation for some economic and social activities (e.g., common field management, cattle herding, participation in rituals, bridewealth payment), the brief description of Masa household composition and agricultural practices invites us to consider separately each household member's activities and decision-making patterns. In consequence, a household member's strategy should not be conflated with an a priori uniform household strategy, nor should the behavior of a single member (i.e., the household head) be considered representative of all other household members' behaviors. Furthermore, it cannot be expected that a household head systematically provides reliable information as to the diversity of choices made by his coresidents.

\section{Data collection}

\section{Defining household and individual characteristics}

Data concerning sorghum seed acquisitions were gathered during the 2011-2012 cropping season. Fifteen of the village's 183 households were chosen to represent a three-level gradient of socioeconomic status (Table 1). Based on the local conceptions of wealth, household socioeconomic status was divided into three socioeconomic strata: poor, intermediate, and wealthy. Household inclusion in any one stratum was determined by four variables: estimated size of cattle herd, number of spouses, household members' average cropped sorghum area, and possession of an ox-plough or other animal-driven tools.
All the active members of the surveyed households were interviewed, bringing the total number of informants to 70 . The interviewing of an equivalent number of households in each socioeconomic stratum combined with the generally greater number of farmers in wealthy households led to an overrepresentation of farmers from the richest households in our sample compared to the entire population (Table 1). We have paid special attention to the potential effects our sampling structure may have on the results. We consequently provide a method for raking our sample (i.e., sample balancing; see Data analysis) and discuss its implications. Our sample included a greater number of women (Table 1), which resulted from the widespread practice of polygyny ( 9 of the 15 households included a polygamous marriage). Age of farmers ranged from 16 to 81 years old. Three different age categories were created: young $(<30)$, mid-aged $(30$ $50)$, and old $(>50)$. These categories were defined so that each contained an equivalent number of informants while maintaining coherent age classes in terms of agricultural activity.

Collection and characterization of seed circulation data

Data concerning seed acquisition events were gathered through a standardized protocol that aimed to collect information on the type of acquired landrace and the nature of the relationship between provider and recipient. For each informant, the inventory of all landraces grown during the 2011-2012 cropping season was established. Subsequently, informants were asked to mention, for each landrace, its most recent external source (e.g., other than own seed production) and the number of years since the event occurred. Informants were not asked to mention people to whom they had given seeds because we rapidly realized that they were much more forgetful and less accurate for these events.

Market seed sources, for which an individual provider of seed was not identifiable, were distinguished from all other sources. For each other seed acquisition event, the provider's geographical location was recorded, and the relationship between recipient and provider was documented. Three categories of seed source were established according to the residence of the seed provider: within household, within village, and outside village. Kinship relationships between provider and recipient were described with precision and cross-referenced with a genealogical data set (containing 2546 individuals) that we had gathered through our ethnographic fieldwork in the village. All of the recorded kin relationships were grouped into three categories: spouse (husband and wife relationships), paternal or maternal kin (all bloodrelated parents), and in-laws (any relationship established through one or several marriages, except spouse). Because a woman's kin are her husband's in-laws, and vice versa, kin relationships mentioned by a woman were recoded in reference to her husband. In consequence, the in-laws category includes the actual in-laws 
Fig. 1. Documented seed acquisition network. Blue, interviewed individuals; dark green, identified sources within the village; light green, identified sources outside the village. Cirlces, women; triangles, men.

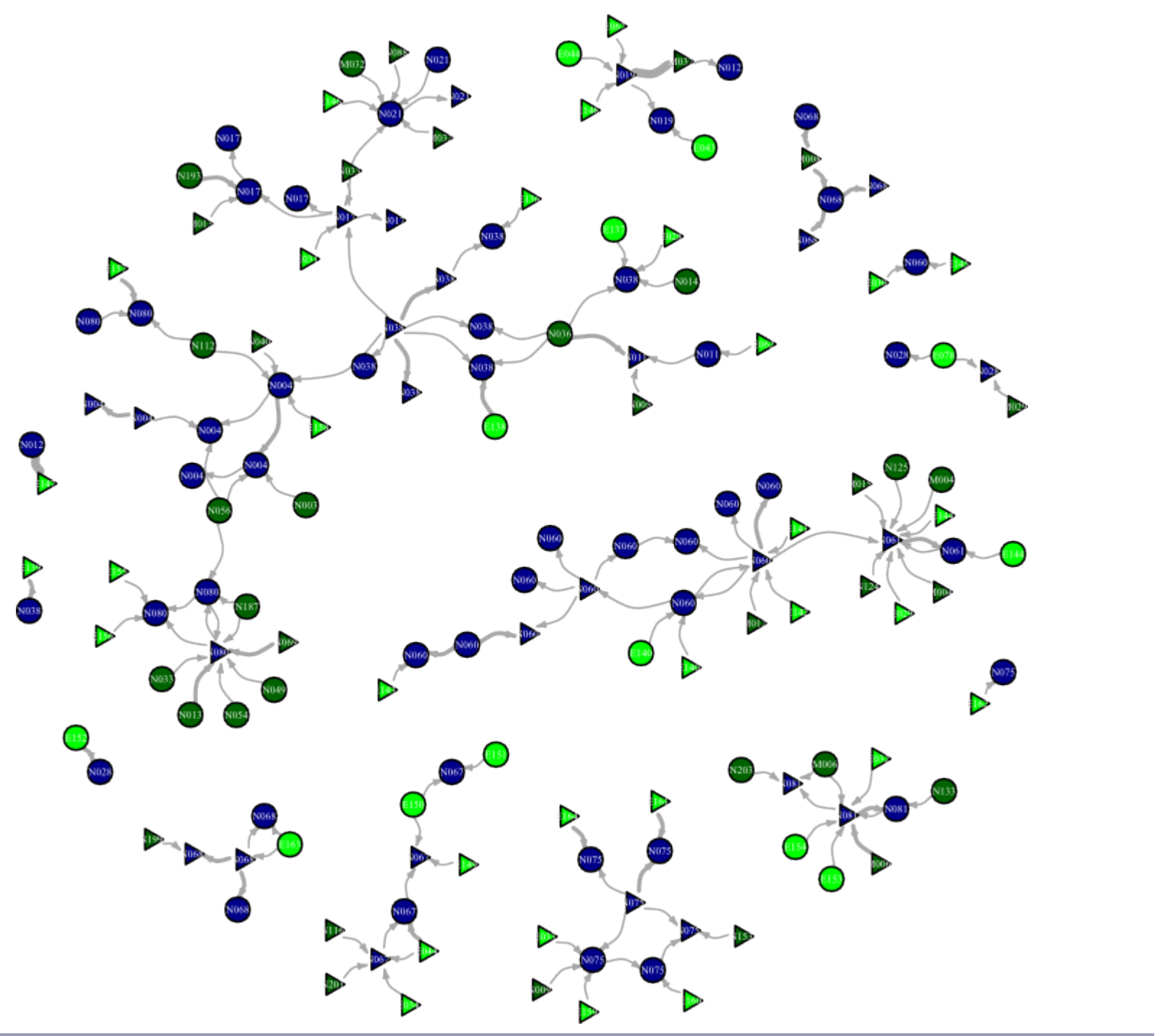

mentioned by men and the kin mentioned by women. This recoding provides, in sociological terms, the least heterogeneous categories: individuals in the paternal and maternal kin category are directly related to Nuldayna's main lineage, and the in-laws category includes individuals belonging to different and more distant lineages. Providers who were not kin-related to the interviewee were presented either as neighbors, friends, or members of the local catholic mission and were recorded as such.

Landraces were grouped into two broad types: common (7 landraces) and rare (13 landraces). The classification is based on previous surveys concerning local ethnobotanical knowledge of sorghum landraces (Garine et al. 2013), an extensive inventory of grown landraces at the village scale (Thomas et al. 2015), and the actual frequency with which landraces were grown by farmers in our survey.

\section{Data analysis}

We used a mixed quantitative and qualitative approach to analyze our data. Results from the SNA of our seed circulation data are interpreted and discussed in light of qualitative data we gathered throughout our fieldwork in the village.

The relational data concerning the seed acquisition events is represented as a seed circulation network. The network may be visualized and analyzed either with nodes representing individual farmers $(N=70)$ or with nodes representing households $(N=15$; Table 1). In both cases, edges represent a seed acquisition event between a seed provider and a seed recipient. All edges were drawn from the information given by recipients.

It is important to stress some peculiarities of the seed circulation network (Fig. 1). First, the network edges are oriented: they represent a directional flow from seed provider to seed recipient and may not be considered reciprocal. Second, the network is an 
assemblage of ego-centered networks for which information was gathered only for incoming events (i.e., seed acquisitions). Third, the network is structurally very open because farmers may acquire seeds from a multitude of different seed providers both within and outside the village community. Therefore, information is scarce for nodes mentioned outside the village and is incomplete concerning pairs of nodes for which no seed transfer is documented.

The network characteristics preclude the use of SNA methods such as the quadratic assignment procedure (Krackhardt 1987, Dekker et al. 2007) or exponential random graph models (Snijders et al. 2006), which were developed for closed social networks (i.e., networks in which nodes belong to a neatly bounded community and edges link only pairs of nodes belonging to that community; a fully observed network with no missing edges). Thus, we conducted independence tests between variables concerning node and edge attributes. However, the results of independence tests should be interpreted with caution because, by definition, relational data observations are not completely independent. Pearson's chisquare tests were used preferentially. When the minimum expected value of any cell within a tested frequency distribution of events was $<5$, Fisher's exact tests for count data were used. Analyses were carried out using the "stats" package (version 3.0.2), and network representations were performed using the "igraph" package (version 0.6.6; Csardi and Nepusz 2006), both using R (version 3.1.2; R Core Team 2014). Statistical significance was set at $\alpha=$ 0.05 .

Our goals for SNA were twofold. First, we wished to understand the biases that may arise when considering households rather than individual farmers as the network nodes. To do this, two networks were generated: one represents farmer-to-farmer seed flows and the other household-to-household seed flows. For both, the number of grown landraces as well as network characteristics such as weighted in-degree (total number of incoming seed events) and in-degree (number of different seed sources) were computed for each node.

Second, we wanted to explore the influences that node attributes may have on the characteristics of the edges. Three variables were used to characterize the network nodes: household socioeconomic status, gender, and age. Edges were described based on three variables: category of seed source, kinship relationship between recipients and providers, and types of landraces.

Because household size and wealth levels are highly correlated, a greater number of informants belonging to wealthy households were interviewed (Table 1). Thus, for tests on variables other than household socioeconomic status, it was necessary to weigh the contribution of individuals from each socioeconomic stratum in accordance with the observed ratio of wealthy to intermediate to poor households in the entire village population (Table 1). For instance, when considering any two variables other than socioeconomic status (e.g., gender and landrace type), the frequency distribution of seed acquisition events for these two variables was computed for each socioeconomic stratum separately. Then, before summing the three distributions, each one was factored by the ratio of actual number of households from that stratum in the whole village (e.g., 13 wealthy households) to total number of households in the village (183 households; Table 1 ). This raking procedure enables us to limit the sampling variance. Results from tests with and without raking are indicated.

\section{RESULTS AND DISCUSSION}

\section{Description of the seed circulation network}

In total, 223 seed acquisition events were documented through interviews with 70 farmers concerning the origin of landraces grown during the 2011-2012 cropping season. Among these, 31 events $(14 \%)$ originated either from the local village market $(17$ events) or from five other more distant market places. The remaining 192 nonmarket seed acquisition events involved 157 different farmers either as seed providers, seed recipients, or both (Fig. 1). Even though market-based events were considered in our analyses (except when taking into consideration the variable concerning kinship relationships, which represent $78 \%$ of total events), we think it is unsuitable to represent markets as nodes alongside nodes representing individual farmers. The farmers we surveyed mentioned 111 different seed providers, of which only 24 belonged to the group of interviewees; of the remaining 87 , one-half (43) live in the village of Nuldayna, and the other half live in 28 other villages.

This brief description of the network illustrates the extent to which it is structurally open. In fact, the network is poorly connected, counting 12 different components, and its density is low (0.006). These network characteristics partly result from collecting data from a subsample of the entire village population. They can also be explained by the fact that farmers may have their own seed sources outside the village. Density would have been higher (0.012) had we considered households as network nodes. However, we argue that such a choice would present a distorted image of the local dynamics of seed circulation.

\section{Household-level analyses provide an imperfect image of the local seed system}

The tendency to document and analyze local seed systems at the household level may cause several biases in SNA results and their interpretation. In our case study, quite different results are provided from household- and individual-based analyses. For each socioeconomic stratum, number of grown landraces, weighted in-degree, and in-degree were averaged by the number of households and by the number of individual farmers (Table 2). At the household level, socioeconomic status is correlated with a higher weighted in-degree (23.25 on average for wealthy households vs. 11.2 for the poorest ones) and a slightly broader diversity of seed sources (as shown by in-degree of 11.5 on average for the wealthiest households vs. 8.3 and 8.6 for intermediate and poor households). Such correlations are an indirect result of the greater number of interviewed farmers in the wealthiest households and cannot be accounted for by wealth alone. Number of grown landraces, which is less dependent on household size because several farmers from the same household may grow the same landraces, is similar among the socioeconomic strata. Number of landraces is more dependent on individual characteristics such as age and gender. Men grow a slightly higher number of landraces (mean $\pm \mathrm{SD}, 3.4 \pm 2.4$ landraces) than women (2.6 \pm 1.0 landraces). The average number of landraces also tends to increase with farmer age $(3.7 \pm 1.9$ landraces for the eldest farmers and $2.2 \pm 1.1$ landraces for the youngest ones).

It can be expected that observed differences between households of different socioeconomic status disappear when focusing on individuals because these differences are mainly driven by household size and composition. However, at the individual level, 
Table 2. Number of grown landraces, weighted in-degree, and in-degree by socioeconomic stratum.

\begin{tabular}{llcccc}
\hline \hline Level of study & $\begin{array}{l}\text { Socioeconomic } \\
\text { status }\end{array}$ & $\begin{array}{c}\text { Number of } \\
\text { nodes }\end{array}$ & $\begin{array}{c}\text { Mean number of grown } \\
\text { landraces (SD) }\end{array}$ & Mean weighted in-degree (SD) & Mean in-degree (SD) \\
\hline Nodes indicate & Wealthy & 4 & $7.25(0.9)$ & $23.25(2.6)$ & $11.5(2.6)$ \\
households & Intermediate & 5 & $7.2(3.1)$ & $12.3(4.9)$ & $8.3(3.2)$ \\
& Poor & 6 & $6.6(1.7)$ & $11.2(6.0)$ & $8.6(4.8)$ \\
& Total & 15 & $7.0(2.1)$ & $14.9(6.9)$ & $9.3(3.7)$ \\
Nodes indicate & Wealthy & 36 & $2.4(1.0)$ & $2.6(1.1)$ & $2.0(1.0)$ \\
individuals & Intermediate & 22 & $3.1(2.1)$ & $3.4(2.4)$ & $2.8(1.8)$ \\
& Poor & 12 & $3.8(2.0)$ & $3.7(2.5)$ & $3.8(2.0)$ \\
& Total & 70 & $2.9(1.7)$ & $3.2(2.0)$ & $2.6(1.8)$ \\
\hline
\end{tabular}

an inverted trend appears: members of wealthy households tend to request seeds from fewer people and to grow fewer landraces than do members of other households (Table 2). An interpretation of such a trend could be that farmers of poor and small households need to be more active in seed-seeking than do those of wealthy households because they are more affected by grain shortages and seed loss. Moreover, with fewer coresidents from whom to access seeds, they are driven to seek seeds outside of the household. Inversely, in wealthy households it appears that only a small number of farmers grow a broad spectrum of landraces and provide other coresidents, each season, with the seeds of landraces they wish to grow.

The frequent occurrences of intrahousehold events is, certainly, the most important dimension of the network that would be discarded by focusing on households rather than individuals as the unit of analysis. For each socioeconomic stratum, a substantial proportion of seed exchanges is transacted within households. Approximately one-third (31\%) of wealthy individuals' seed acquisitions occur within the household (Fig. 2). This can be explained by the higher number of active farmers in these households. However, even within the poorest households, such events represent $21 \%$ of all seed acquisitions and underscore the importance of seed transactions between spouses. These results are in accordance with those provided by case studies conducted in other cultural settings in which researchers have pointed to the frequent occurrence of intrahousehold seed provisioning (Zimmerer 2003, van Etten and de Bruin 2007). Intrahousehold dynamics are a key component of the local seed system, suggesting that household-level analyses, as well as gathering data from a single informant, cannot provide an accurate image of the actual patterns of seed circulation.

Household heads are not representative of all household members Here, we address the biases that would be introduced in the analyses of the effects of household socioeconomic status on individuals' seed-seeking behavior had we only interviewed household heads. We analyzed both the complete sample (all household members) and a subset comprising only household heads. For independence tests carried out between socioeconomic strata and characteristics of the seed acquisition events, the only difference between both samples is in the types of acquired landraces (Table 3). Although no significant preference appears when comparing household heads, the distribution of events concerning all household members indicates that members of the wealthiest households tend to acquire more common landraces (which represent $90 \%$ of events documented in the stratum) than those of the poorest households, who proportionately seek rare landraces more often $(36 \%$ of the events documented in the stratum). This pattern results from the cumulative effect of taking into account all the seed acquisitions of those active farmers from wealthy households who grow a small number of common landraces.

Fig. 2. Number of seed acquisition events based on household $(\mathrm{HH})$ socioeconomic status and seed source. (a) Household heads (Fisher's exact test, $P=0.009$ ). (b) All household members (Pearson's chi-square test, $P=0.037$ ).

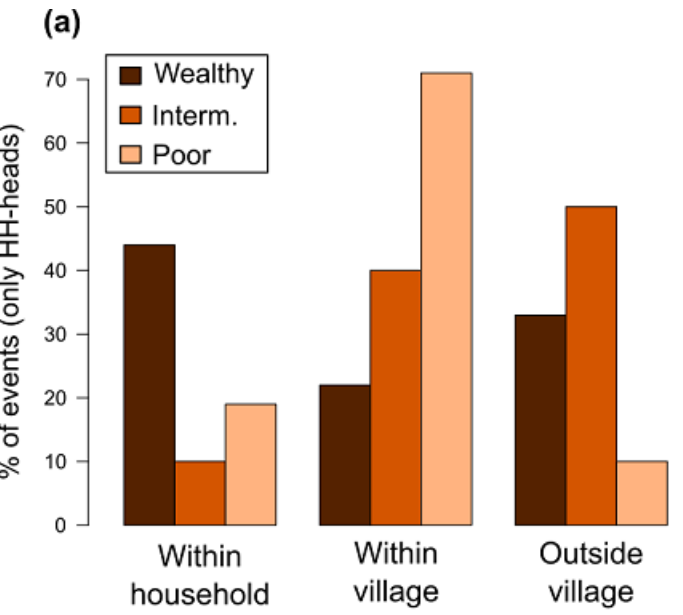

(b)

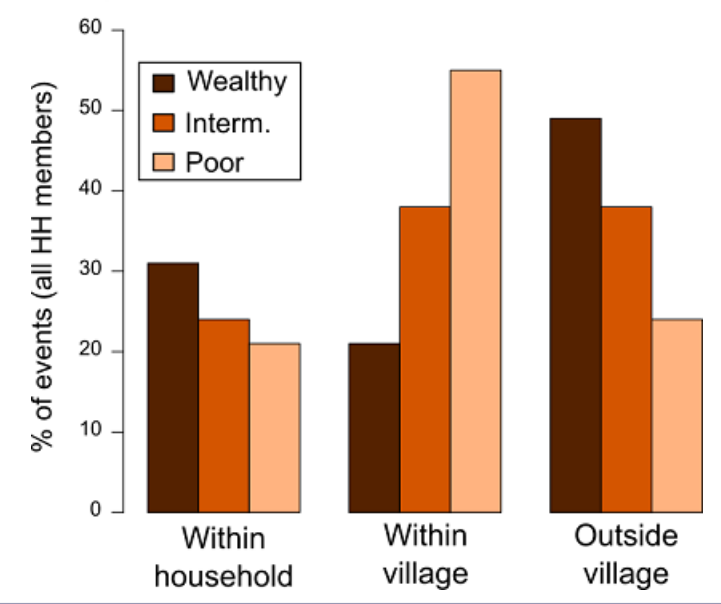


Table 3. Results of independence tests between farmer characteristics and properties of seed acquisition events. When considering all household members, $N=223$ events. Market acquisitions are not considered in the kinship relationships variable $(N=192)$.

\begin{tabular}{|c|c|c|c|c|}
\hline Variable & Data set & Seed source category & Kinship relationship & Type of landrace \\
\hline Household socioeconomic status & $\begin{array}{l}\text { Only household heads } \\
\text { All household members }\end{array}$ & $\begin{array}{c}0.009 * \star(N=71) \\
0.037 * \S\end{array}$ & $\begin{array}{c}0.732^{\ddagger}(N=61) \\
0.751^{\ddagger}\end{array}$ & $\begin{array}{c}0.435^{\ddagger}(N=71) \\
0.012^{*} \S\end{array}$ \\
\hline Gender & $\begin{array}{l}\text { Unraked sample } \\
\text { Raked sample }\end{array}$ & $\begin{array}{l}0.092^{\dagger \S} \\
0.069^{\dagger \S}\end{array}$ & $\begin{array}{c}0.013^{*} \\
0.333^{\star}\end{array}$ & $\begin{array}{l}0.007 * \S \\
0.037 * \S\end{array}$ \\
\hline Age & $\begin{array}{l}\text { Unraked sample } \\
\text { Raked sample }\end{array}$ & $\begin{array}{l}0.002^{*} \$ \\
0.034^{*}\end{array}$ & $\begin{array}{l}0.123^{\ddagger} \\
0.484^{\ddagger}\end{array}$ & $\begin{array}{l}0.064^{\dagger \S} \\
0.002^{\dagger \S}\end{array}$ \\
\hline
\end{tabular}

$* P<0.05,{ }^{\dagger} P<0.1$.

${ }^{\ddagger}$ Fisher test.

${ }^{\S}$ Chi-square test.

When considering the categories of seed source in relation to socioeconomic strata, tests are statistically significant for both the entire sample and the subset (Table 3). However, the actual frequency distributions of events for the tested variables (Fig. 2a, b) show that the significant dependencies are not the same. Differences between the two samples are small for the lowest stratum. In fact, regardless of the tested sample, members from poor and small households seem to prefer seed sources from within the village than from more distant villages. The smaller frequency of intrahousehold seed sources for those individuals stems from the fewer number of coresidents in the household. The discrepancies between the distribution patterns of the two samples are strongest for wealthy households. Although wealthy household heads seem to rely mostly, but not exclusively, on intrahousehold seed sources (Fig. 2a), taking into account the seed sources from all other members of their household reveals a clear preference for long-distance provisioning outside the village (Fig. 2b). This is mainly due to the incorporation of seed acquisitions from the greater number of women present in wealthy households. Identifying that seed sources are more scattered geographically in wealthy households than in other households would not have been possible had we only interviewed household heads.

\section{Age- and gender-related patterns of seed acquisition}

Effect of farmer age on preferred seed sources and landraces Independence tests carried out between individual-level properties and characteristics of seed acquisition events indicate that age is an important factor in understanding farmers' preferred seed sources and types of landraces (Table 3). Independence tests performed for categories of seed source (Fig. 3a) clearly reveal younger farmers' preference for intrahousehold seed provisioning and their low proportion of seed sources outside the village. Mid-aged farmers, inversely, are those whose external seed sources are the most important. The proportion dwindles for older farmers, for which intravillage seed sources are the most important and intrahousehold acquisitions are relatively low. Such patterns may be understood by the changes in farmers' involvement in agricultural activities across their life-span. Because most young farmers tend to stay in their father's (or, for women, father-in-law's) household, the pool of social relationships they have access to is smaller than for older individuals. In fact, some of the young people interviewed were not yet married and acquired most of their seeds directly from their father or mother. In contrast, mid-aged farmers' preference for seed sources outside the village is the result of the greater dynamism with which they engage in economic activities. Midaged farmers are the most mobile, frequently traveling outside the village to visit friends and in-laws (e.g., for work aid or funerals) or for economic reasons (e.g., going to different markets to buy or sell crops and cattle). They are also those who crop the largest fields and who prove to be the most innovative by their willingness to try out new crops or new sorghum landraces.

Fig. 3. Number of seed acquisition events based on age, seed source, and type of landrace. (a) Age and seed source (raked sample; Fisher's exact test, $P=0.0034$ ). (b) Age and type of landrace (raked sample; Pearson's chi-square test, $P=0.002$ ).
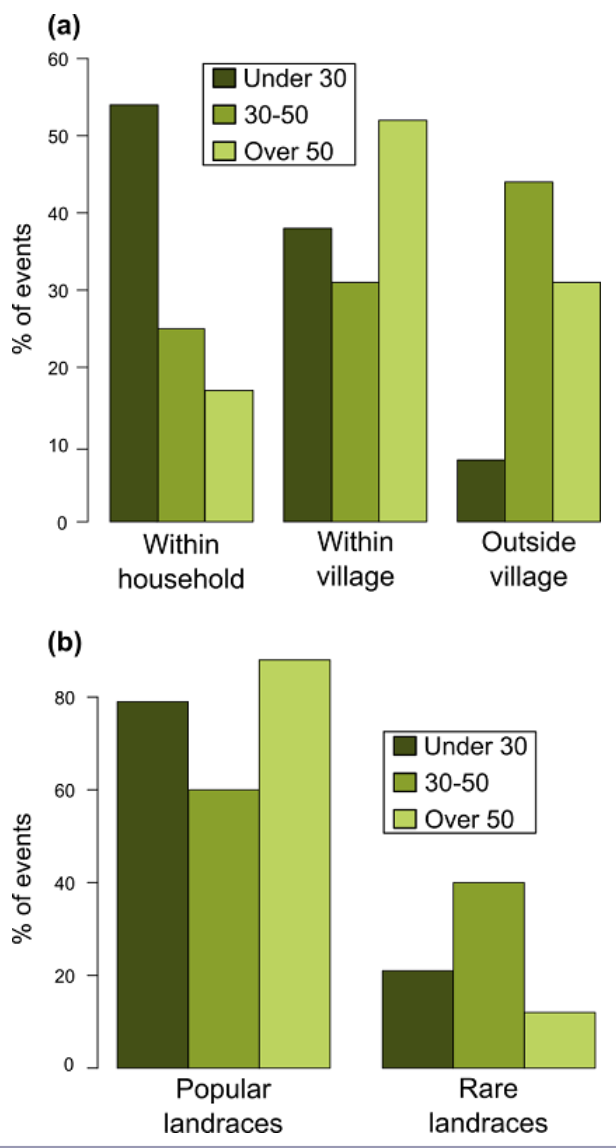
The dynamism of mid-aged farmers is further revealed because they seek out and actually grow a larger proportion of rare landraces than do farmers in other age categories. The independence test on the types of acquired landraces (common vs. rare) in relation to age is statistically significant (Table 3), and the actual distribution supports this result (Fig. 3b). The distribution also indicates that the older farmers acquired the lowest proportion of rare varieties. This result is consistent with other results concerning the oldest farmers' seed sources, which are mostly located within the village. Less mobile, less invested in farming activities, and more involved in issues relating to politics and ritual, the older farmers acquire common landraces from people of their age category within the village. In fact, the small proportion of intrahousehold seed sources in this age category results from older people's reluctance to acquire seeds from younger coresidents (Table 4). In the 59 intrahousehold seed acquisition events for which the age of both recipients and providers is known, older farmers acted mostly as seed providers and rarely acquired seeds from younger coresidents. In contrast, younger farmers relied mostly on their elders for seed provisioning. Alvarez et al. (2005) note a similar pattern of unidirectional seed flows from older to younger generations of farmers in another farming community in Cameroon.

Table 4. Age of providers and recipients for intrahousehold seed transactions. Fisher's exact test, $P=0.062$.

\begin{tabular}{lccc}
\hline \hline & \multicolumn{3}{c}{ Age of recipient } \\
\cline { 2 - 4 } $\begin{array}{l}\text { Age of } \\
\text { provider }\end{array}$ & Young & Mid-aged & Old \\
\hline Young & 3 & 1 & 0 \\
Mid-aged & 4 & 8 & 2 \\
Old & 21 & 8 & 12 \\
\hline
\end{tabular}

\section{Women's contributions to long-distance exchanges}

Compared to men, women acquire seeds from outside the village more frequently. This is supported by the results from the independence test carried out on gender in relation to categories of seed source and categories of kinship relationships (Table 3). Whereas the tests on raked and unraked samples concerning categories of seed source were not significant at the $\alpha=0.05$ threshold, their relatively low and similar $P$-values $(P<0.1)$ deserve attention. An interesting result is that both distributions of events point to different dependencies (Fig. 4). For the unraked sample, dependencies are driven both by women's greater preference for extravillage seed sources and by men's tendency to engage in intravillage exchanges (Fig. 4a). The residuals from the test on the raked distribution, however, indicate that differences are mainly driven by men's preference. In the raked distribution, women's proportion of extravillage seed sources is slightly higher than that of men, but the proportion is similar to the two other categories of seed source (within village and within household; Fig. 4b). The pattern is similar when looking at tests concerning the categories of kinship relationships men and women have mobilized to acquire seeds (Table 3). The test on the unraked distribution is significant (with women's preference for acquiring seeds from their own patrilineal kin), whereas the test carried out on the raked distribution loses significance.
To understand such discrepancies and their implications, it is necessary to remember why the survey sample was raked. Raking is used to lower the disproportionately high contribution (due to sample stratification) of wealthy individuals to the distribution of events because they are far less represented in the total population. The loss of significance when accounting for the raked distribution suggests that women's preference for longdistance exchanges observed in the unraked distribution is driven by the greater number of wealthy women. In fact, it is women from the wealthiest households who mostly engage in longdistance exchanges with their own kin. Of the 61 extravillage transactions for which the end recipients were women, $51 \%$ were received by women belonging to the highest socioeconomic stratum. Women from wealthy households, in which polygyny is frequent, have greater opportunity to leave the house and to travel more often to their native village than do women from poor and monogamous households. Also, the need for seed may be more urgent in the poorest households, driving both men and women to acquire seeds locally from neighbors within the village because it is the most cost-effective manner in terms of both time and energy to obtain them. Thus, while individual characteristics (age and gender) are important in understanding diversity in seedseeking behaviors, household-level properties also explain patterns of seed provisioning.

Fig. 4. Number of seed acquisition events based on gender and seed source. (a) Unraked sample (Pearson's chi-square test, $P=$ 0.002). (b) Raked sample (Pearson's chi-square test, $P=0.069$ ).

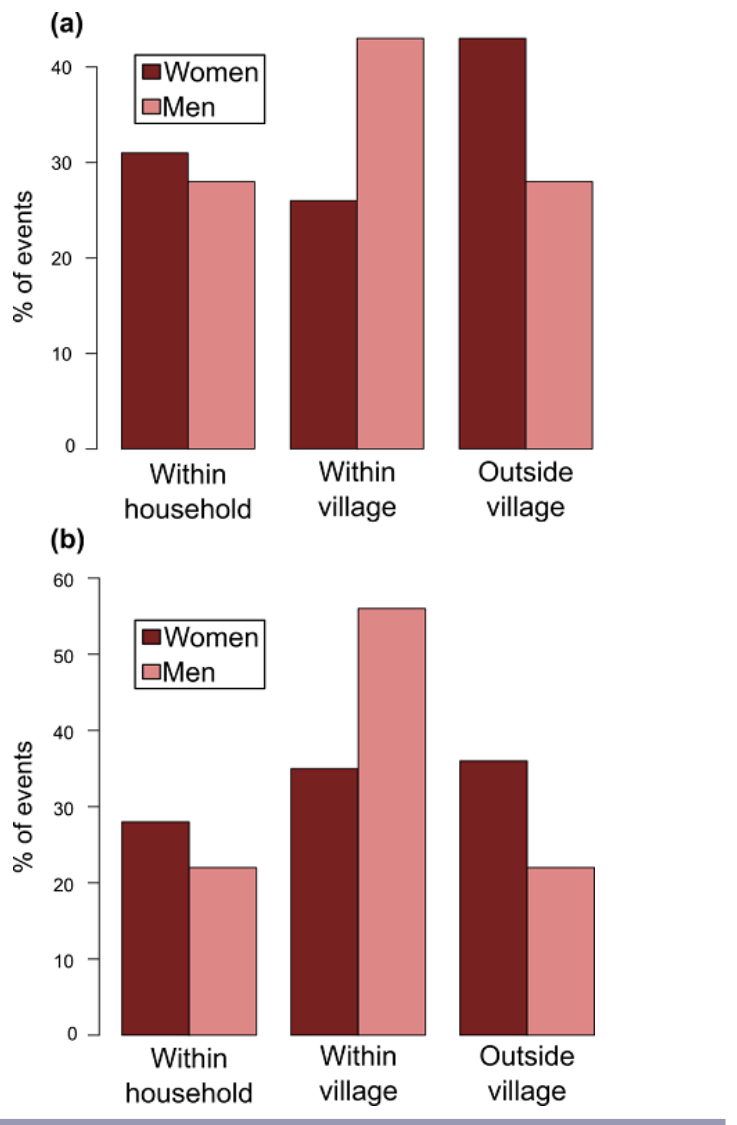


Finally, women tended to acquire a greater proportion of common landraces, as indicated by the statistical significance of the test carried out on gender in relation to types of landraces (Table 3). This result is unexpected. We expected that women's slight preference for long-distance exchanges would be related to their seeking rare and foreign landraces. The fact that women travel to acquire seeds of common landraces from their native village, instead of acquiring them from neighbors in their husband's village, indicates that seed availability is not the only factor involved in the choice of seed sources (Badstue et al. 2007, Bishaw et al. 2010). In times of hardship (famine or seed loss), while opportunities to acquire seeds of common landraces locally are important, men are reluctant to ask their neighbors and patrilineal kin for them and rather have their wives turn to their parents to seek assistance. The reasons underlying such behaviors are twofold. First, men do not wish to overtly display, within the neighborhood, their inability to preserve their seed lots from one season to the other and would rather be indebted to their in-laws than to their blood-related kin (Wencélius and Garine 2014). Second, according to cultural norms, refusing assistance to a daughter who made the effort to visit her parents is strongly disapproved, whereas refusing assistance to a brother or neighbor is more acceptable (Violon et al. 2016).

\section{CONCLUSION}

The first contribution of our work is empirical. Results from the social network analysis of seed circulation in Nuldayna, combined with our understanding of Masa society, revealed distinct patterns of farmer seed sourcing according to age and gender. Both cultural norms (reluctance of elders to depend on younger individuals) and social rules (patrilineal descent, patrilocal residence, and exogamic matrimonial unions) shed light on the local seed system dynamics. Interhousehold heterogeneity in size and level of wealth are also important determinants of individuals' behaviors. The peculiarities of Masa household composition and social stratification entail uneven access to seed sources for farmers. Wealthy households benefit from a greater geographical and sociological diversity of seed sources because they are large formations containing several farmers who acquire their seeds through different channels. The role of women is particularly important in ensuring an almost unconditional access to seed from distant sources through their kin relationships. Frequent intrahousehold seed transactions (between spouses and from older to younger generations) provide members from the wealthiest and largest households with ready access to seed and contribute to making them more seed secure than farmers of lower socioeconomic status. These findings were obtained because of an anthropologically informed understanding of what the notion of household actually refers to in the cultural context of our study, and by accounting for within-community variation in household characteristics.

A second contribution of our paper is methodological. Several implications stem from our research and may be useful for future research designs aiming to document seed circulation networks through the use of SNA. First, it appears that inferring household-level behaviors from data collected from a single household member is not satisfactory, at least in our case study. Indeed, such practices may induce substantial biases in analyses and fail to account for intrahousehold dynamics of seed transactions. Intrahousehold dynamics are a key component of local seed systems, and disregarding them affects the understanding of how farmers are capable of accessing and maintaining high levels of crop diversity. Second, interviewing several members from each household offers researchers the possibility of incorporating in their sample a larger array of actors along with their contrasting behaviors. Third, greater attention should be dedicated to within-community patterns of interhousehold heterogeneity and their influences on individual behavior. For studies of community-level properties of seed circulation networks, variation in household characteristics should be reflected in the sampling design.

We hope that the methodological recommendations that have emerged from our case study will contribute to further discussions on sampling techniques for seed circulation networks. While results from both our research and existing literature (Louette et al. 1997, Zimmerer 2003, van Etten 2006) indicate that seed systems are structurally open, little attention has been given to the issues related to using SNA methods, which were developed for closed or complete networks (Wasserman and Faust 1994), in studying seed circulation networks. Beyond any doubt, SNA offers powerful and promising tools for understanding local seed systems. We think that providing methodological guidelines for the ethnographic collection and sampling of relational data of seed transactions is a priority for further studies in this field of research.

Responses to this article can be read online at: http://www.ecologyandsociety.org/issues/responses. $\mathrm{php} / 8208$

\section{Acknowledgments:}

We gratefully acknowledge the French Fondation pour la Recherche sur la Biodiversité (FRB) that made possible NetSeed, an international collaboration of researchers studying farmer seed networks. Mathieu Thomas was provided with six months of postdoctoral funding within this program. The Centre de Synthèse et d'Analyse sur la Biodiversité (CESAB) provided essential logistical support for regular workshops on the subject, which enabled us to develop and mature both the theoretical and methodological aspects of our research. Additional support of the ongoing research collaboration through the MIRES and MADRES networks was provided by the following agencies: the Réseau National des Systèmes Complexes (RNSC), the Institut National de la Recherche Agronomique (INRA), and the Centre National de la Recherche Scientifique (CNRS). We are most thankful for the patience and time that farmers from Nuldayna have generously offered to answer our questions and to share their daily experiences. This work would not have been possible without continual help from Maïtouda Denis Wakna, our research assistant in the field.

\section{LITERATURE CITED}

Abay, F., W. de Boef, and Å. Bjørnstad. 2011. Network analysis of barley seed flows in Tigray, Ethiopia: supporting the design of strategies that contribute to on-farm management of plant genetic resources. Plant Genetic Resources 9(4):495-505. http://dx.doi. org/10.1017/s1479262111000773 
Almekinders, C. J. M., N. P. Louwaars, and G. H. de Bruijn. 1994. Local seed systems and their importance for an improved seed supply in developing countries. Euphytica 78(3):207-216. http:// dx.doi.org/10.1007/bf00027519

Alvarez, N., E. Garine, C. Khasah, E. Dounias, M. HossaertMcKey, and D. McKey. 2005. Farmers' practices, metapopulation dynamics, and conservation of agricultural biodiversity on-farm: a case study of sorghum among the Duupa in sub-Sahelian Cameroon. Biological Conservation 121(4):533-543. http://dx.doi. org/10.1016/j.biocon.2004.05.021

Augustins, G. 1998. La perpétuation des groupes domestiques: un essai de formalisation. L'Homme 38(148):15-45. http://dx.doi. org/10.3406/hom.1998.370574

Badstue, L. B., M. R. Bellon, J. Berthaud, X. Juárez, I. M. Rosas, A. M. Solano, and A. Ramírez. 2006. Examining the role of collective action in an informal seed system: a case study from the central valleys of Oaxaca, Mexico. Human Ecology 34(2):249-273. http://dx.doi.org/10.1007/s10745-006-9016-2

Badstue, L. B., M. R. Bellon, J. Berthaud, A. Ramírez, D. Flores, and X. Juárez. 2007. The dynamics of farmers' maize seed supply practices in the central valleys of Oaxaca, Mexico. World Development 35(9):1579-1593. http://dx.doi.org/10.1016/j. worlddev.2006.05.023

Ban, N., and O. T. Coomes. 2004. Home gardens in Amazonian Peru: diversity and exchange of planting material. Geographical Review 94(3):348-367. http://dx.doi.org/10.1111/j.1931-0846.2004. $\underline{\mathrm{tb} 00177 . \mathrm{x}}$

Bellon, M. R. 2004. Conceptualizing interventions to support onfarm genetic resource conservation. World Development 32 (1):159-172. http://dx.doi.org/10.1016/j.worlddev.2003.04.007

Bentley, J. W., P. van Mele, and D. J. Reece. 2011. How seed works. Pages 8-24 in P. van Mele, J. W. Bentley, and R. G. Guéi, editors. African seed enterprises: sowing the seeds of food security. CABI, Wallingford, UK. http://dx.doi.org/10.1079/9781845938437.0008

Bishaw, Z., P. C. Struik, and A. J. G. Van Gastel. 2010. Wheat seed system in Ethiopia: farmers' varietal perception, seed sources, and seed management. Journal of New Seeds 11 (4):281-327. http://dx.doi.org/10.1080/1522886x.2010.518302

Boster, J. S. 1986. Exchange of varieties and information between Aguaruna manioc cultivators. American Anthropologist 88 (2):428-436. http://dx.doi.org/10.1525/aa.1986.88.2.02a00100

Calvet-Mir, L., M. Calvet-Mir, J. L. Molina, and V. Reyes-García. 2012. Seed exchange as an agrobiodiversity conservation mechanism. A case study in Vall Fosca, Catalan Pyrenees, Iberian Peninsula. Ecology and Society 17(1):29. http://dx.doi. org/10.5751/ES-04682-170129

Chambers, K. J., and S. B. Brush. 2010. Geographic influences on maize seed exchange in the Bajío, Mexico. Professional Geographer 62(3):305-322. http://dx.doi.org/10.1080/00330124.$\underline{2010.483624}$

Coomes, O. T. 2010. Of stakes, stems, and cuttings: the importance of local seed systems in traditional Amazonian societies. Professional Geographer 62(3):323-334. http://dx.doi. org/10.1080/00330124.2010.483628
Csardi, G., and T. Nepusz. 2006. The igraph software package for complex network research. Inter Journal Complex Systems:1695. [online] URL: http://igraph.org

de Garine, I. 1964. Les Massa du Cameroun, vie économique et sociale. PUF, Paris, France.

Dekker, D., D. Krackhardt, and T. A. B. Snijders. 2007. Sensitivity of MRQAP tests to collinearity and autocorrelation conditions. Psychometrika 72(4):563-581. http://dx.doi.org/10.1007/ s11336-007-9016-1

Delêtre, M., D. B. McKey, and T. R. Hodkinson. 2011. Marriage exchanges, seed exchanges, and the dynamics of manioc diversity. Proceedings of the National Academy of Sciences 108 (45):18249-18254. http://dx.doi.org/10.1073/pnas.1106259108

Dumas-Champion, F. 1983. Les Masa du Tchad: bétail et société. Cambridge University Press, Cambridge, UK.

Dyer, G. A., C. González, and D. C. Lopera. 2011. Informal "seed" systems and the management of gene flow in traditional agroecosystems: the case of cassava in Cauca, Colombia. PLoS One 6(12):e29067. http://dx.doi.org/10.1371/journal.pone.0029067

Ellen, R., and S. Platten. 2011. The social life of seeds: the role of networks of relationships in the dispersal and cultural selection of plant germplasm. Journal of the Royal Anthropological Institute 17(3):563-584. http://dx. doi.org/10.1111/j.1467-9655.2011.01707. $\underline{x}$

Garine, É, A. Barnaud, and C. Raimond. 2014. Quel pourrait être le territoire des semences des sorghos que cultivent les Duupa du Massif de Poli (Nord du Cameroun)? Les Cahiers d'Outre-Mer 265:67-92.

Garine, E., A. Luxereau, J. Wencélius, C. Violon, T. Robert, A. Barnaud, S. Caillon, and C. Raimond. 2013. De qui les variétés traditionnelles de plantes cultivées pourraient-elles être le patrimoine? Réflexions depuis le bassin du lac Tchad. Pages 379-409 in D. Juhé-Beaulaton, M.-C. Cormier-Salem, P. D. Robert, and B. Roussel, editors. Effervescence patrimoniale au Sud: entre nature et société. IRD, Marseille, France.

Gastellu, J.-M., and J.-L. Dubois. 1997. En économie: l'unité retrouvée, la théorie revisitée. Pages 75-97 in M. Pilon, T. Locoh, E. Vignikin, and P. Vimard, editors. Ménages et familles en Afrique: approches des dynamiques contemporaines. CEPED, Paris, France.

Goody, J. 1958. The developmental cycle in domestic groups. Cambridge University Press, Cambridge, UK.

Hodgkin, T., R. Rana, J. Tuxill, D. Balma, A. Subedi, I. Mar, D. Karamura, R. Valdivia, L. Collado, L. Latournerie, M. Sadiki, M. Sawadogo, A. H. D. Brown, and D. I. Jarvis. 2007. Seed systems and crop genetic diversity in agroecosystems. Pages 77-116 in D. I. Jarvis, C. Padoch, and H. D. Cooper, editors. Managing biodiversity in agricultural ecosystems. Columbia University Press, New York, New York, USA.

Kawa, N. C., C. McCarty, and C. R. Clement. 2013. Manioc varietal diversity, social networks, and distribution constraints in rural Amazonia. Current Anthropology 54(6):764-770. http://dx. doi.org/10.1086/673528 
Krackhardt, D. 1987. QAP partialling as a test of spuriousness. Social Networks 9(2):171-186. http://dx.doi.org/10.1016/0378-8733 (87) $90012-8$

Labeyrie, V., B. Rono, and C. Leclerc. 2014. How social organization shapes crop diversity: an ecological anthropology approach among Tharaka farmers of Mount Kenya. Agriculture and Human Values 31(1):97-107. http://dx.doi.org/10.1007/ s10460-013-9451-9

Leclerc, C., and G. Coppens d'Eeckenbrugge. 2012. Social organization of crop genetic diversity. The $\mathrm{G} \times \mathrm{E} \times \mathrm{S}$ interaction model. Diversity 4(1):1-32. http://dx.doi.org/10.3390/d4010001

Lipper, L., C. L. Anderson, and T. J. Dalton, editors. 2009. Seed trade in rural markets: implications for crop diversity and agricultural development. Routledge, London, UK.

Longley, C. A. 2000. A social life of seeds: local management of crop variability in north-western Sierra Leone. Dissertation. University College London, London, UK.

Louette, D., A. Charrier, and J. Berthaud. 1997. In situ conservation of maize in Mexico: genetic diversity and maize seed management in a traditional community. Economic Botany 51 (1):20-38. http://dx.doi.org/10.1007/bf02910401

Louwaars, N. P., and W. S. de Boef. 2012. Integrated seed sector development in Africa: a conceptual framework for creating coherence between practices, programs, and policies. Journal of Crop Improvement 26(1):39-59. http://dx.doi.org/10.1080/15427$\underline{528.2011 .611277}$

McGuire, S. J. 2008. Securing access to seed: social relations and sorghum seed exchange in eastern Ethiopia. Human Ecology 36 (2):217-229. http://dx.doi.org/10.1007/s10745-007-9143-4

Nagarajan, L., M. Smale, and P. Glewwe. 2007. Determinants of millet diversity at the household-farm and village-community levels in the drylands of India: the role of local seed systems. Agricultural Economics 36(2):157-167. http://dx.doi.org/10.1111/ j.1574-0862.2007.00195.x

Netting, R. M., R. R. Wilk, and E. J. Arnould, editors. 1984. Households: comparative and historical studies of the domestic group. University of California Press, Berkeley, California, USA.

Niehof, A. 2011. Conceptualizing the household as an object of study. International Journal of Consumer Studies 35(5):488-497. http://dx.doi.org/10.1111/j.1470-6431.2011.01026.x

Pautasso, M., G. Aistara, A. Barnaud, S. Caillon, P. Clouvel, O. T. Coomes, M. Delêtre, E. Demeulenaere, P. de Santis, T. Döring, L. Eloy, L. Emperaire, E. Garine, I. Goldringer, D. Jarvis, H. I. Joly, C. Leclerc, S. Louafi, P. Martin, F. Massol, S. McGuire, D. McKey, C. Padoch, C. Soler, M. Thomas, and S. Tramontini. 2013. Seed exchange networks for agrobiodiversity conservation. A review. Agronomy for Sustainable Development 33(1):151-175. http://dx.doi.org/10.1007/s13593-012-0089-6

Perales, H. R., B. F. Benz, and S. B. Brush. 2005. Maize diversity and ethnolinguistic diversity in Chiapas, Mexico. Proceedings of the National Academy of Sciences 102(3):949-954. http://dx.doi. org/10.1073/pnas.0408701102

Poudel, D., B. Sthapit, and P. Shrestha. 2015. An analysis of social seed network and its contribution to on-farm conservation of crop genetic diversity in Nepal. International Journal of Biodiversity 2015:312621. http://dx.doi.org/10.1155/2015/312621

Pressoir, G., and J. Berthaud. 2004. Patterns of population structure in maize landraces from the Central Valleys of Oaxaca in Mexico. Heredity 92:88-94. http://dx.doi.org/10.1038/sj. $\underline{\text { hdy. } 6800387}$

R Core Team. 2014. R: a language and environment for statistical computing. $\mathrm{R}$ foundation for Statistical Computing, Vienna, Austria. [online] URL: http://www.R-project.org/

Rana, R. B., C. J. Garforth, B. R. Sthapit, and D. I. Jarvis. 2011. Farmers' rice seed selection and supply system in Nepal: understanding a critical process for conserving crop diversity. International Journal of Agricultural Science 1(5):258-274.

Raynaut, C. 1977. Aspects socio-économiques de la préparation et de la circulation de la nourriture dans un village Hausa (Niger). Cahiers d'Etudes Africaines 17(68):569-597. http://dx.doi. org/10.3406/cea.1977.2431

Reyes-García, V., J. L. Molina, L. Calvet-Mir, L. Aceituno-Mata, J. J. Lastra, R. Ontillera, M. Parada, M. Pardo-de-Santayana, M. Rigat, J. Vallès, and T. Garnatje. 2013. "Tertius gaudens": germplasm exchange networks and agroecological knowledge among home gardeners in the Iberian Peninsula. Journal of Ethnobiology and Ethnomedicine 9:53-62. http://dx.doi. org/10.1186/1746-4269-9-53

Ricciardi, V. 2015. Social seed networks: identifying central farmers for equitable seed access. Agricultural Systems 139:110-121. http://dx.doi.org/10.1016/j.agsy.2015.07.002

Samberg, L. H., C. Shennan, and E. Zavaleta. 2013. Farmer seed exchange and crop diversity in a changing agricultural landscape in the Southern Highlands of Ethiopia. Human Ecology 41 (3):477-485. http://dx.doi.org/10.1007/s10745-013-9579-7

Seboka, B., and A. Deressa. 1999. Validating farmers' indigenous social networks for local seed supply in central rift valley of Ethiopia. Journal of Agricultural Education and Extension 6 (4):245-254. http://dx.doi.org/10.1080/13892240085300071

Snijders, T. A. B., P. E. Pattison, G. L. Robins, and M. S. Handcock. 2006. New specifications for exponential random graph models. Sociological Methodology 36(1):99-153. http://dx. doi.org/10.1111/j.1467-9531.2006.00176.x

Sperling, L., and S. McGuire. 2010. Understanding and strengthening informal seed markets. Experimental Agriculture 46(2):119-136. http://dx.doi.org/10.1017/s0014479709991074

Stone, M. P., G. D. Stone, and R. M. Netting. 1995. The sexual division of labor in Kofyar agriculture. American Ethnologist 22 (1):165-186. http://dx.doi.org/10.1525/ae.1995.22.1.02a00080

Stromberg, P. M., U. Pascual, and M. R. Bellon. 2010. Seed systems and farmers' seed choices: the case of maize in the Peruvian Amazon. Human Ecology 38(4):539-553. http://dx.doi. org/10.1007/s10745-010-9333-3

Subedi, A., P. Chaudhary, B. K. Baniya, R. B. Rana, R. K. Tiwari, D. K. Rijal, B. R. Sthapit, and D. I. Jarvis. 2003. Who maintains crop genetic diversity and how? Implications for on-farm conservation and utilization. Culture and Agriculture 25(2):41-50. http://dx.doi.org/10.1525/cag.2003.25.2.41 
Thiele, G. 1999. Informal potato seed systems in the Andes: Why are they important and what should we do with them? World Development 27(1):83-99. http://dx.doi.org/10.1016/S0305-750X (98)00128-4

Thomas, M., E. Demeulenaere, J. C. Dawson, A. R. Khan, N. Galic, S. Jouanne-Pin, C. Remoue, C. Bonneuil, and I. Goldringer. 2012. On-farm dynamic management of genetic diversity: the impact of seed diffusions and seed saving practices on a population-variety of bread wheat. Evolutionary Applications 5(8):779-795. http://dx.doi.org/10.1111/

j.1752-4571.2012.00257.X

Thomas, M., N. Verzelen, P. Barbillon, O. T. Coomes, S. Caillon, D. McKey, M. Elias, E. Garine, C. Raimond, E. Dounias, D. Jarvis, J. Wencélius, C. Leclerc, V. Labeyrie, P. H. Cuong, N. T. N. Hue, B. Sthapit, R. B. Rana, A. Barnaud, C. Violon, L. M. Arias Reyes, L. Latournerie Moreno, P. De Santis, and F. Massol. 2015. A network-based method to detect patterns of local crop biodiversity: validation at the species and infra-species levels. Advances in Ecological Research 53:259-320. http://dx.doi. org/10.1016/bs.aecr.2015.10.002

van Etten, J. 2006. Molding maize: the shaping of a crop diversity landscape in the western highlands of Guatemala. Journal of Historical Geography 32(4):689-711. http://dx.doi.org/10.1016/j. jhg.2005.12.002

van Etten, J., and S. de Bruin. 2007. Regional and local maize seed exchange and replacement in the western highlands of Guatemala. Plant Genetic Resources 5(2):57-70. http://dx.doi. org/10.1017/s147926210767230x

Vazquez-Garcia, V. 2003. Whose money is it? Cattle production and household income allocation in southern Veracruz, Mexico. International Journal of Agricultural Resources, Governance and Ecology 2(2):140-152. http://dx.doi.org/10.1504/ijarge.2003.002083

Violon, C., T. Thomas, and E. Garine. 2016. Good year, bad year: changing strategies, changing networks? A two-year study on seed acquisition in Northern Cameroon. Ecology and Society 21(2) in press.

Wasserman, S., and K. Faust. 1994. Social network analysis: methods and applications. Cambridge University Press, Cambridge, UK. http://dx.doi.org/10.1017/cbo9780511815478

Wencélius, J., and É. Garine. 2014. Dans les sillons de l'alliance. Ethnographie de la circulation des semences de sorgho dans l'extrême-Nord du Cameroun. Les Cahiers d'Outre-Mer 265:93-116.

Zimmerer, K. S. 1991. The regional biogeography of native potato cultivars in highland Peru. Journal of Biogeography 18(2):165-178. http://dx.doi.org/10.2307/2845290

Zimmerer, K. S. 2003. Geographies of seed networks for food plants (potato, ulluco) and approaches to agrobiodiversity conservation in the Andean countries. Society and Natural Resources 16(7):583-601. http://dx.doi.org/10.1080/08941920309185 